\title{
Improvement of Properties of Stainless Steel Orthodontic Archwire Using $\mathrm{TiO}_{2}$ :Ag Coating
}

\author{
Zofia Kielan-Grabowska ${ }^{1}$, Justyna Bącela ${ }^{2}$, , Anna Zięty ${ }^{2}$, Wioletta Seremak ${ }^{2}$, Marta Gawlik-Maj ${ }^{3,4}$, \\ Beata Kawala ${ }^{1,3, *}$, Beata Borak ${ }^{2}$, Jerzy Detyna ${ }^{2}$ (D) and Michał Sarul ${ }^{3,4}$ \\ 1 Department of Dentofacial Orthopedics and Orthodontics, Wroclaw Medical University, Krakowska 26, \\ 50-425 Wrocław, Poland; zosia.kielan@gmail.com \\ 2 Department of Mechanics, Materials and Biomedical Engineering, Faculty of Mechanical Engineering, \\ Wrocław University of Science and Technology, Smoluchowskiego 25, 50-372 Wrocław, Poland; \\ justyna.bacela@pwr.edu.pl (J.B.); anna.ziety@pwr.edu.pl (A.Z.); wioletta.seremak@pwr.edu.pl (W.S.); \\ beata.borak@pwr.wroc.pl (B.B.); jerzy.detyna@pwr.edu.pl (J.D.) \\ 3 Academic Dental Polyclinic of Dental Center of Technology Transfer Ltd., Krakowska Str. 26, \\ 50-425 Wroclaw, Poland; marta.gawlik-maj@umed.wroc.pl (M.G.-M.); michal.sarul@gmail.com (M.S.) \\ 4 Department of Integrated Dentistry, Wroclaw Medical University, Krakowska 26, 50-425 Wroclaw, Poland \\ * Correspondence: elzbieta.jankowska@umed.wroc.pl
}

Citation: Kielan-Grabowska, Z; Bącela, J.; Zięty, A.; Seremak, W.; Gawlik-Maj, M.; Kawala, B.; Borak, B.; Detyna, J.; Sarul, M. Improvement of Properties of Stainless Steel Orthodontic Archwire Using $\mathrm{TiO}_{2}: \mathrm{Ag}$ Coating. Symmetry 2021, 13, 1734 https://doi.org/10.3390/sym13091734

Academic Editors: Jerzy Malachowski, Adam Ciszkiewicz, Grzegorz Milewski and Takashiro Akitsu

Received: 31 July 2021

Accepted: 13 September 2021

Published: 18 September 2021

Publisher's Note: MDPI stays neutral with regard to jurisdictional claims in published maps and institutional affiliations.

Copyright: (c) 2021 by the authors. Licensee MDPI, Basel, Switzerland. This article is an open access article distributed under the terms and conditions of the Creative Commons Attribution (CC BY) license (https:/ / creativecommons.org/licenses/by/ $4.0 /)$.
Abstract: Orthodontic treatment carries the risk of major complications such as enamel demineralization, tooth decay, gingivitis, and periodontal damage. A large number of elements of fixed orthodontic appliance results in the creation of additional plaque retention sites which increase the risk of biofilm creation. Modification of the surface of orthodontic elements may prevent the formation of bacterial biofilm. In this paper, surface modification of stainless steel orthodontic wires with $\mathrm{TiO}_{2}$ : Ag was carried out by the sol-gel thin film dip-coating method. To obtain the anatase crystal structure, substrates were calcined for $2 \mathrm{~h}$ at $500{ }^{\circ} \mathrm{C}$. The properties of the obtained coatings were investigated using scanning electron microscopy, $\mathrm{X}$-ray diffraction, and electrochemical tests. Corrosion studies were performed in a Ringer's solution, which simulated physiological solution. SEM and XRD analyses of the coated surface confirmed the presence of Ag nanoparticles which may have antimicrobial potential.

Keywords: coated materials; orthodontic wires; biocompatible; surface properties; microscopy; nanoparticles

\section{Introduction}

The main goal of orthodontic treatment is to improve the function of the masticatory system, but also, to a large extent, to ensure that the smile is aesthetically pleasing. Unfortunately, like most medical procedures, this treatment carries the risk of complications. The main side effects of orthodontic treatment include enamel demineralization, tooth decay, gingivitis and recession, periodontal damage, and root resorption (Figure 1). Therefore, it is justified to take all measures to prevent these negative phenomena $[1,2]$.

Modern orthodontic treatment usually requires the use of a fixed orthodontic appliance. A fixed appliance consists of, among other things, brackets-elements that are located in the patient's mouth throughout the treatment period-and archwires-elements that are replaced at follow-up visits. Chromium-nickel stainless steel $(18-8$, SS) is one of the materials widely used in the manufacture of both brackets and archwires. Due to its mechanical properties, archwires made of this material are used as the main working arches during most orthodontic treatment. A large number of elements contribute to the creation of additional plaque retention sites and thus provide an additional surface on which bacterial biofilm may accumulate [3,4]. Bacterial biofilm is a specialized mono- or multispecies lifeform of microorganisms that is permanently located on a substrate and surrounded by a layer of polysaccharides [5]. The polysaccharide component of the matrix provides many benefits to the cells in the biofilm, such as adhesion and protection [6]. Aside from 
polysaccharides, biofilms consist of proteins, nucleic acids, lipids, and humic substances. The main role of the biofilm is to protect the microbial community from environmental stresses [7].

(a)

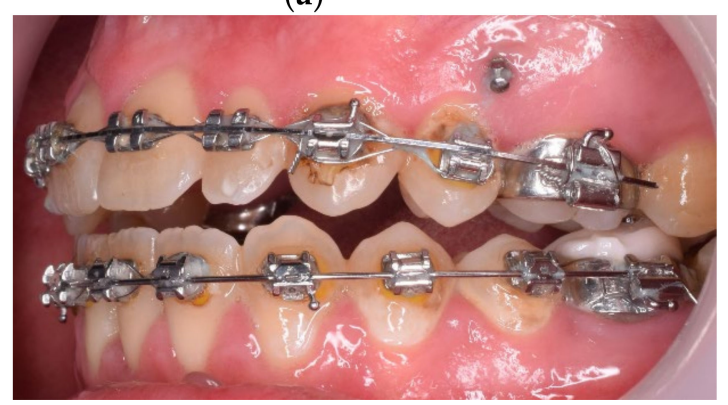

(b)

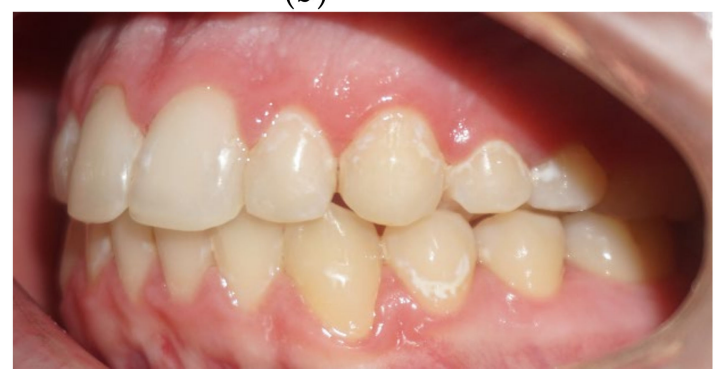

(c)

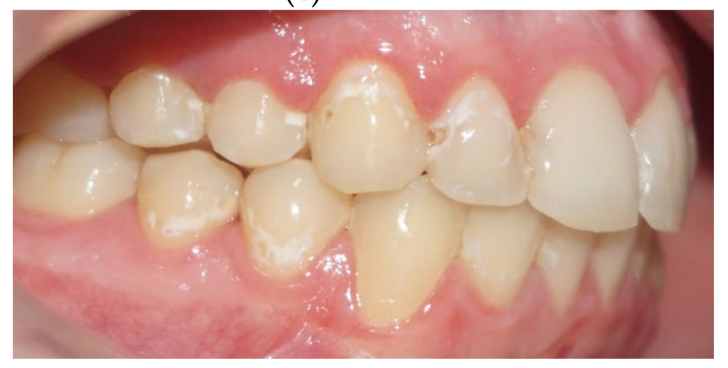

Figure 1. The main side effects of orthodontic treatment and poor oral hygiene during orthodontic treatment (a) plaque accumulation sites around orthodontic braces, $(\mathbf{b}, \mathbf{c})$ white spot lesions, enamel demineralization, and cavity occurred due to fixed orthodontic treatment.

Among the factors influencing the degree of adhesion of bacterial biofilm are the topological and chemical properties of the surface of orthodontic elements. Modification of the surface of orthodontic elements is one of the possibilities to improve their properties, including the prevention of bacterial biofilm formation. Such modifications can be made with the use of additional layers containing compounds that may have a bactericidal or bacteriostatic effect. Coatings used on orthodontic wires may influence their surface characteristics, and, hence, their properties such as: surface roughness [8], mechanical and frictional properties [9], thickness [10], corrosiveness [11], coating stability [12], and bacterial adhesion [13].

Such a coating can be made of titanium dioxide $\left(\mathrm{TiO}_{2}\right)$. According to some researchers, it may provide both antibacterial and anti-corrosion effects $[14,15]$. Strong antibacterial properties were also confirmed in the case of coatings containing silver particles [16]. However, such layers have to meet several preconditions to transition from in vitro to in vivo testing and must then be introduced as a finished product for wide clinical use. Before using cell line testing and subsequent in vivo testing, the product must meet the following essential conditions: maximum film integrity and uniformity, durability in mechanical tests typical for the component material, and corrosion resistance under typical electrochemical conditions in the oral cavity. Obtaining a coating with appropriate properties to a large extent depends on selecting an appropriate method of covering the elements [17]. There 
are many different types of coating techniques such as physical vapor deposition, a thermal evaporation method, radiofrequency magnetron sputtering, and less frequently used solgel thin film dip-coating method [18]. In this study, the sol-gel thin film dip-coating method was used. Its main advantage is a good structure homogeneity, the possibility to control the conductivity of the resulting material, and high purity of starting material $[19,20]$.

The aim of the paper is to present the physicochemical sol-gel process of applying a $\mathrm{TiO}_{2}$ :Ag layer with potential bactericidal properties to 18-8 stainless steel archwires and to present the corrosion behavior of the elements with a modified surface. The main goal is to achieve a proper coating that shows no fractures and no delamination and can be further examined on its probable antibacterial properties. Inventing a coating with perfect adhesion to a stainless steel archwire along with antibacterial properties may eliminate or reduce some of the side effects of orthodontic treatment.

\section{Materials and Methods}

\subsection{Material}

These studies were conducted at the Department of Mechanics, Materials and Biomedical Engineering of Wrocław University of Science and Technology. It involved stainless steel (SS) orthodontic wires $0.016 \times 0.022$ inch (Adenta, Rīga, Latvija). Surface modification of stainless steel orthodontic wires with $\mathrm{TiO}_{2}$ was carried out using the sol-gel thin film dip-coating method. It can be explained in three parts:

\subsubsection{Preparation of $\mathrm{TiO}_{2} \mathrm{Sol}$}

The solution of $\mathrm{TiO}_{2}$ consisted of $6 \mathrm{~mL}$ of titanium(IV) isopropoxide (97\%, Aldrich), $85 \mathrm{~mL}$ of 2-propanol (Eurochem BDG, Tarnów, Poland), and $0.5 \mathrm{~mL}$ of acetic acid (99\%, Aldrich). To reduce surface roughness, polypropylene glycol (PPG, Mw = 1000, Alfa Aesar) at $1 \mathrm{wt}$.\% was added to the $\mathrm{TiO}_{2}$ solution. After adding PPG to the solution, it was stirred up for $3 \mathrm{~h}$ at room temperature using a magnetic stirrer. The stirred sol was aged for $24 \mathrm{~h}$ at $4{ }^{\circ} \mathrm{C}$. The orthodontic wires were then cleaned in an ultrasonic bath before being coated with acetone and distilled water for $15 \mathrm{~min}$. The synthesis of $\mathrm{TiO}_{2}$ sol was based on the modified sol-gel method from Özyildiz F. et al. [21].

\subsubsection{Preparation of $\mathrm{TiO}_{2}: \mathrm{Ag}$ Solution}

In this study, the salt used was silver nitrate $\left(\mathrm{AgNO}_{3}\right.$; Sigma-Aldrich). One gram of $\mathrm{AgNO}_{3}$ was dissolved in a mixture of $2.4 \mathrm{~mL}$ of water, $10 \mathrm{~mL}$ of acetic acid, and $12 \mathrm{~mL}$ of isopropanol. The solution was subsequently mixed with the $\mathrm{TiO}_{2}$ precursor sol for $3 \mathrm{~h}$ at room temperature using a magnetic stirrer. Synthesis of $\mathrm{TiO}_{2}: \mathrm{Ag}$ solution was based on the modified synthesis from Tomás S. et al. [22].

\subsubsection{Preparation of Thin Films}

In this study, stainless steel wires were coated with $\mathrm{TiO}_{2}$ and $\mathrm{TiO}_{2}: \mathrm{Ag}$ layers using the sol-gel dip-coating method. In order to obtain an even coating, each orthodontic wire was dipped in the sol for $1 \mathrm{~min}$ and removed at a constant speed of $65.8 \mathrm{~mm} / \mathrm{min}$. Substrates were dried for $1 \mathrm{~h}$ at $120{ }^{\circ} \mathrm{C}$ with a heating and cooling rate of $0.5{ }^{\circ} \mathrm{C} / \mathrm{min}$. This procedure was repeated twice to increase the thickness of the thin film. The coated wires were then calcined for $2 \mathrm{~h}$ at $500{ }^{\circ} \mathrm{C}$ with a heating and cooling rate of $1^{\circ} \mathrm{C} / \mathrm{min}$ (Nabertherm Industrial Furnaces LT 5/11/P330).

\subsubsection{Preparation of $\mathrm{TiO}_{2}$ and $\mathrm{TiO}_{2}$ :Ag Powders}

In this study, $\mathrm{TiO}_{2}$ and $\mathrm{TiO}_{2}: \mathrm{Ag}$ powders were also carried out to analyze the crystal structure using $\mathrm{X}$-ray diffraction. The powders were obtained by drying hydrolysates of $\mathrm{TiO}_{2}$ and $\mathrm{TiO}_{2}$ :Ag at room temperature for seven days and dried at $120^{\circ} \mathrm{C}$ for $1 \mathrm{~h}$ with a heating and cooling rate of $0.5^{\circ} \mathrm{C} / \mathrm{min}$. The obtained powder samples were heated for $2 \mathrm{~h}$ at $500{ }^{\circ} \mathrm{C}$ with a heating and cooling rate of $1^{\circ} \mathrm{C} / \mathrm{min}$.

The final division of the subgroups of the studied material is presented in Table 1. 
Table 1. Groups of samples used for studies.

\begin{tabular}{cl}
\hline Group 1 & $\begin{array}{l}\text { Control group-it consisted of uncoated stainless steel orthodontic wires } \\
\text { Experimental group-it consisted of surface-modified stainless steel orthodontic } \\
\text { wroup 2 }\end{array}$ \\
wroup 3 & $\begin{array}{l}\text { Experimental group-it consisted of surface-modified stainless steel orthodontic } \\
\text { wires coated with } \mathrm{TiO}_{2}: \mathrm{Ag} \text { thin film }\end{array}$ \\
\hline
\end{tabular}

\subsection{Characterization}

\subsubsection{Scanning Electron Microscopy}

Surface morphology and composition of the coated wires with $\mathrm{TiO}_{2}$ and $\mathrm{TiO}_{2}: \mathrm{Ag}$ were analyzed by scanning electron microscopy (SEM S-3400N HITACHI) equipped with an energy dispersive X-ray (EDS) detector.

\subsubsection{X-ray Diffraction}

$\mathrm{X}$-ray diffraction (XRD) measurements were performed on an X-ray diffractometer Ultima IV (Rigaku, Japan), with CuK $\alpha$ irradiation $(\lambda=1.54056 \AA)$ in the range of angles $2 \theta$ from $10^{\circ}$ to $85^{\circ}$, a step of 0.05 and exposure time $1 \mathrm{~s}$ per point.

\subsubsection{Electrochemical Measurements}

In order to prepare samples for electrochemical tests, selected parts of archwires were mounted in the Duracryl Plus epoxy resin according to the scheme below (Figure 2). For the next step, each working surface was cleaned with acetone in an ultrasonic bath.

Before the linear potentiodynamic polarization tests, each alloy was tested for $1 \mathrm{~h}$ for open-circuit potential measurements. Electrochemical reactions occurred on the metalsolution interaction when metals were submerged in a simulated oral environment, i.e., Ringer's solution. After that, electrochemical measurements were performed in a conventional three-electrode cell. A saturated calomel electrode (SCE) was used as a reference, and a platinum plate-as the counter electrode. Measurements were performed using the Atlas 0531 potentiostat.

After $1 \mathrm{~h}$ of immersion in the test solution, the corrosion behavior of bare and coated archwire samples was evaluated using polarization curves and potentiostatic corrosion tests. The potential scan rate was $1 \mathrm{mV} / \mathrm{s}$. Data were analyzed using the Tafel extrapolation method. All measurements were performed at room temperature.

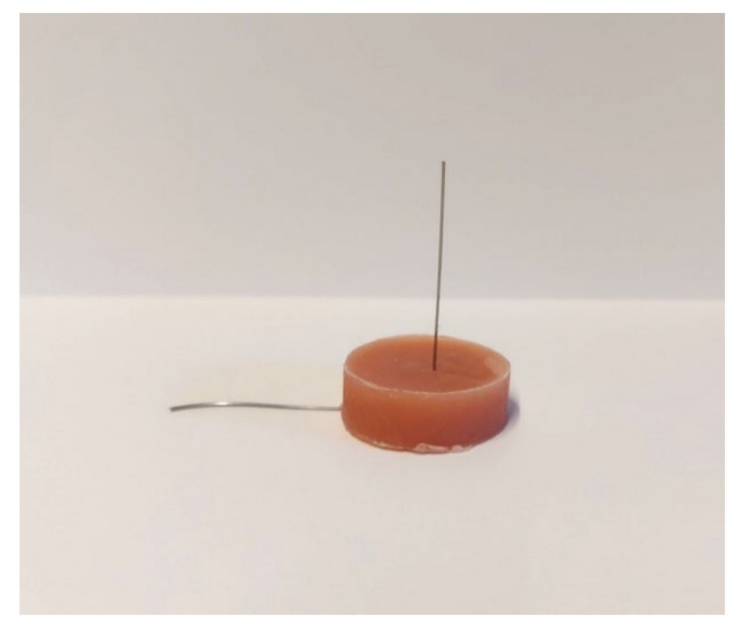

Figure 2. The sample of archwire prepared for the electrochemical test.

\section{Results}

\subsection{SEM Analysis}

Morphologies of the samples were observed using SEM (Figure 3), the material composition of each uncoated and coated orthodontic wire was determined. Figure $3 a-c$ 
shows the morphology of uncoated samples and samples coated with $\mathrm{TiO}_{2}$ and $\mathrm{TiO}_{2}: \mathrm{Ag}$. The analysis was performed using the SEM technique, via which the anchorage on the surface of the wires was checked. It can be seen that the surface of $\mathrm{TiO}_{2}$ and $\mathrm{TiO}_{2}: \mathrm{Ag}$ coated wires is smooth and cracking as well as delamination of the coatings are not observed. The presence of silver was confirmed by the EDX analysis and elemental mapping.

(a)

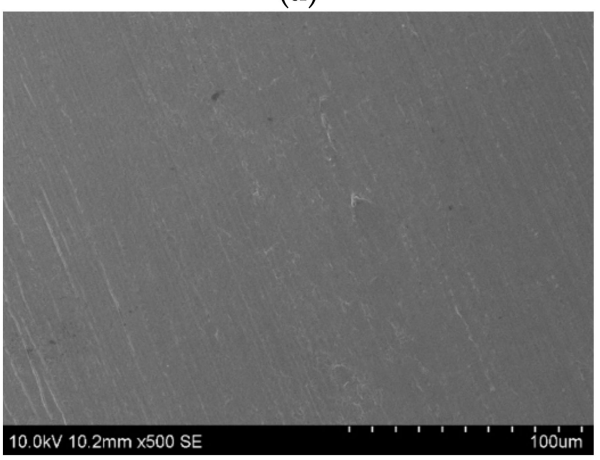

(c)

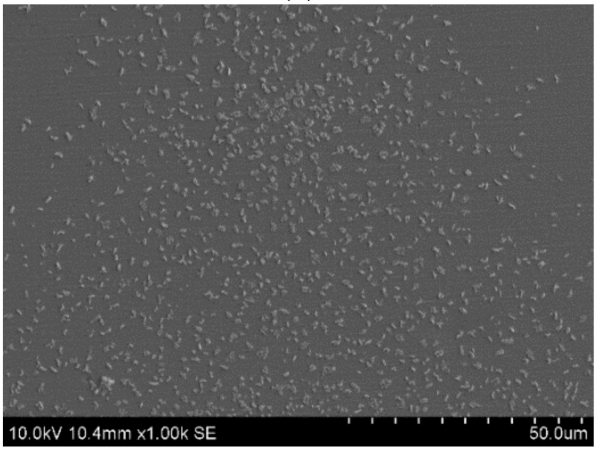

(b)

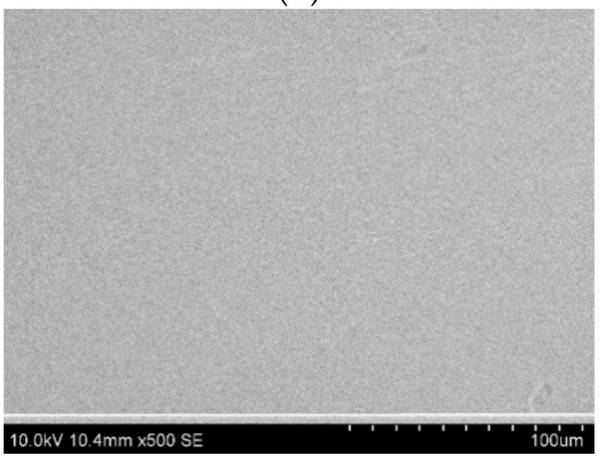

(d)

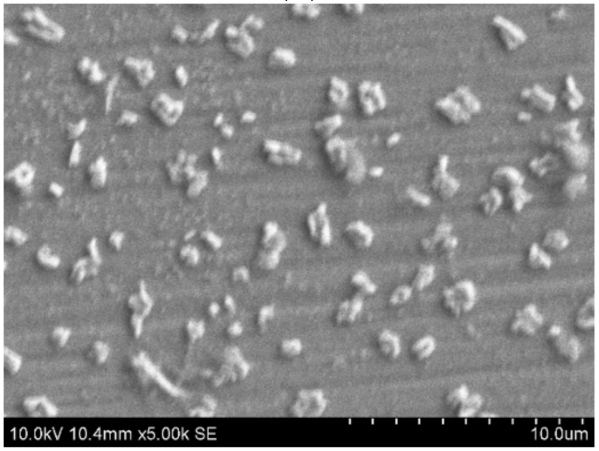

Figure 3. Representative micrographs from the SEM of uncoated (a), coated with $\mathrm{TiO}_{2}(\mathbf{b})$ and coated with $\mathrm{TiO}_{2}: \mathrm{Ag}(\mathbf{c}, \mathrm{d})$ stainless steel orthodontic wires.

$\mathrm{TiO}_{2}$ :Ag samples (Figure 3c,d) showed a greater number of aggregated $\mathrm{TiO}_{2}$ particles at the end of the wire section, and thus present a larger specific surface area than control $\mathrm{TiO}_{2}$ films (Figure 3b); accordingly, an enhanced photocatalytic activity is expected, since a greater number of reactive sites is available to participate in photoreactions. Based on the results of the energy-dispersive X-ray spectroscopy (EDS) results, it was found that the grains observed in the SEM images are mainly constituted by $\mathrm{TiO}_{2}$ with doping levels of Ag. It was also found that Ag aggregated into particles, but these particles were larger and much more spread in the film than the $\mathrm{TiO}_{2}$ particles.

\subsection{XRD Analysis}

X-ray diffraction analysis of the powders presented in Figure 4 shows patterns of the above-mentioned $\mathrm{TiO}_{2}$ and $\mathrm{TiO}_{2}$ modified with $\mathrm{Ag}$, both calcined for $2 \mathrm{~h}$ at $500{ }^{\circ} \mathrm{C}$. A, B, $\mathrm{R}, \mathrm{Ag}$ correspond to anatase, brookite, rutile, and silver phases, respectively. For the base $\mathrm{TiO}_{2}$ powder, we observe peaks referring to the anatase phase with the main diffraction peak at $2 \Theta=25.25$. The temperature of $500{ }^{\circ} \mathrm{C}$, which was used for calcination suffices to start the rutile phase crystallization, as evidenced by the diffraction peak at $2 \Theta=27.35$. The XRD pattern of the modified powder shows no signs of rutile crystallization; on the other hand, we observed a hump located at $2 \Theta=31^{\circ}$ which refers to the brookite peak. Main brookite peaks are located near $2 \Theta=25^{\circ}$ and are covered by anatase peaks. Another difference between the powders is the intensity of the peak near $2 \Theta=38^{\circ}$, which, apart from the anatase phase, may refer to the main peak of metallic silver. There are also new peaks at $2 \Theta=43.5,64.3$, and 77.25, which directly confirmed the presence of metallic silver in the powder. 


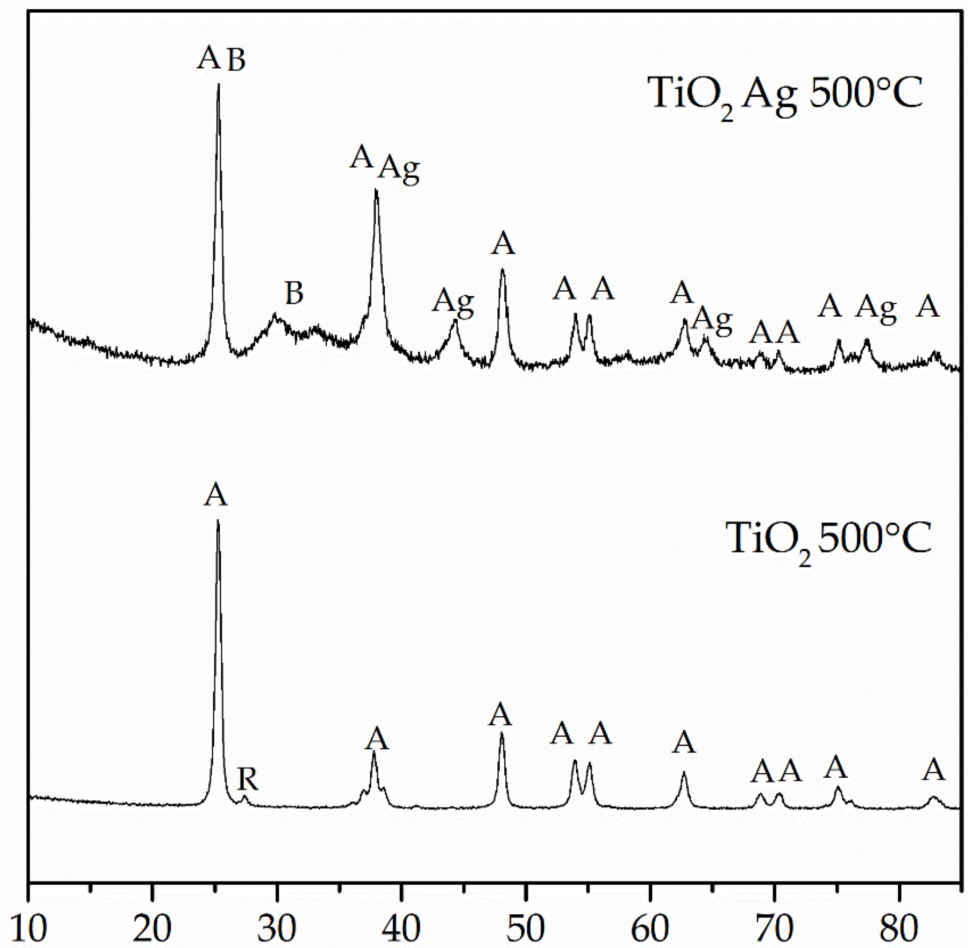

$2 \theta$

Figure 4. The $\mathrm{XRD}$ patterns of powders: $\mathrm{TiO}_{2}$ at the bottom and $\mathrm{TiO}_{2}$ modified with $\mathrm{Ag}$ at the top, both for $2 \mathrm{~h}$ at $500{ }^{\circ} \mathrm{C}$.

\subsection{Corrosion Behavior}

Polarization curves of untreated, $\mathrm{TiO}_{2}$ coated and $\mathrm{Ag}$-doped $\mathrm{TiO}_{2}$ coated samples of stainless steel archwires were investigated by means of electrochemical polarization measurements in a Ringer's solution. Corrosion parameters such as open-circuit potential $\left(\mathrm{E}_{\mathrm{OCP}}\right)$, corrosion potential ( $\left.\mathrm{E}_{\mathrm{corr}}\right)$, corrosion current density $\left(\mathrm{i}_{\mathrm{corr}}\right)$, and anodic/cathodic Tafel slope $\left(\mathrm{B}_{\mathrm{a}}\right.$ and $\left.\mathrm{B}_{\mathrm{c}}\right)$, obtained from polarization curves with the use of Tafel extrapolation, are presented in Table 2 . In addition, polarization resistance $\left(R_{p}\right)$ was determined using the typical Stern-Geary equation [23].

Table 2. Obtained results of corrosion parameters.

\begin{tabular}{ccccccc}
\hline Sample & $\mathbf{E}_{\mathbf{O C P}}(\mathbf{m V})$ & $\mathbf{E}_{\mathbf{c o r r}}(\mathbf{m V})$ & $\mathbf{i}_{\text {corr }}\left(\boldsymbol{\mu} \mathbf{A} \cdot \mathbf{c m}^{-2}\right)$ & $\mathbf{B}_{\mathbf{a}}(\mathbf{m V} / \mathbf{d e c})$ & $\mathbf{B}_{\mathbf{c}}(\mathbf{m V} / \mathbf{d e c})$ & $\left.\mathbf{R}_{\mathbf{p}}(\mathbf{M} \mathbf{\Omega} \cdot \mathbf{c m})^{2}\right)$ \\
\hline Group 1 & 31 & -162 & 0.007 & 129 & 210 & 3.31 \\
Group 2 & -270 & -300 & 39.9 & 177 & 716 & 0.01 \\
Group 3 & -332 & -285 & 30.0 & 165 & 109 & 0.03 \\
\hline
\end{tabular}

Open-circuit potential measurements (OCP) performed after $1 \mathrm{~h}$ are shown in Figure 5. The curves show the potentials versus time of the selected untreated stainless steel archwires and stainless steel archwires with a modified surface. The obtained results for bare SS samples show that the potential $\mathrm{E}_{\mathrm{OCP}}$ increased suddenly. This indicates the passivation of this material, which can also be seen at the next stage of electrochemical tests. Furthermore, the continued shift of potential to positive values indicates that there were changes in the passive layer [24,25]. The potential equals about $-300 \mathrm{mV}$ vs. SCE compared to specimens of archwires with coatings, which can be evaluated as the initiation of localized corrosion or tendency to corrode. However, subsequent investigations revealed that these potential decreases might be related to cathodic inhibition [26]. Moreover, a shift of $E_{\mathrm{OCP}}$ towards 
positive values also for a SS archwire sample with a $\mathrm{TiO}_{2}$ layer was observed. It indicates that this specimen could also form a passive oxide layer.

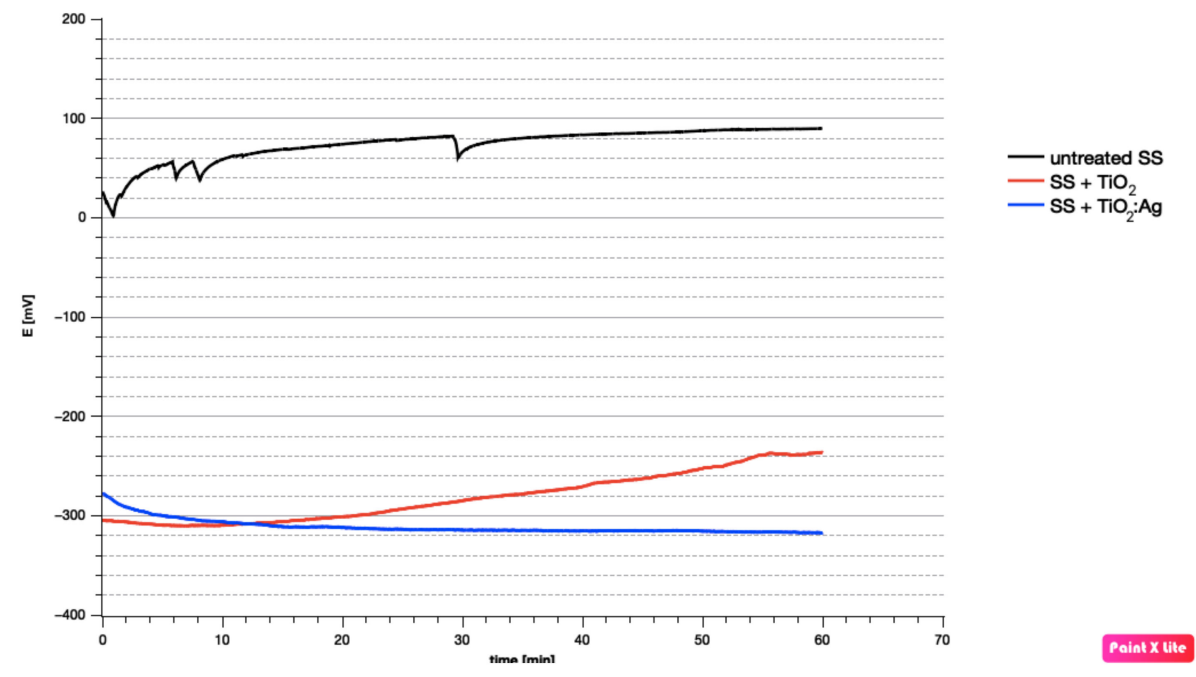

Figure 5. Open-circuit potential curves regarding the $1 \mathrm{~h}$ immersion of bare, $\mathrm{TiO}_{2}$ coated and Ag-doped $\mathrm{TiO}_{2}$ coated selected samples.

When the obtained results of corrosion parameters were examined, it was observed that samples of stainless steel with $\mathrm{TiO}_{2}$ and Ag-doped $\mathrm{TiO}_{2}$ coatings exhibited a remarkable decrease in corrosion resistance [27]. Values of corrosion current density of the bare material were four orders of magnitude lower than the corrosion current density for the coated samples. Another important parameter for determining the corrosion behavior of the samples is polarization resistance. While the $\mathrm{R}_{\mathrm{p}}$ value for untreated SS archwire was $3.31 \mathrm{M} \Omega \cdot \mathrm{cm}^{2}$, polarization resistance of $\mathrm{TiO}_{2}$ and Ag-doped $\mathrm{TiO}_{2}$ coatings were measured as only $0.01 \mathrm{M} \Omega \cdot \mathrm{cm}^{2}$ and $0.03 \mathrm{M} \Omega \cdot \mathrm{cm}^{2}$. In addition, group 2 and group 3 exhibited more negative $\mathrm{E}_{\mathrm{corr}}$ than the uncoated sample, which initially might indicate localized corrosion. Corrosion potentials of the sample with $\mathrm{TiO}_{2}$ and Ag-doped $\mathrm{TiO}_{2}$ coatings are almost similar and are equal to $-270 \mathrm{mV}$ and $-332 \mathrm{mV}$, respectively. At the same time, $\mathrm{E}_{\text {corr }}$ for untreated archwires is $31 \mathrm{mV}$.

Potentiodynamic polarization curves, presented in Figure 6, confirmed that the results obtained for Group 1 are quite different than the other samples. Focusing on the anode region of the polarization curves, uncoated samples show a clear region of passivation. However, further observations revealed that the remaining curves also showed a slight increase in the anode slope. A small area of passivation was especially observed in the case of samples with un-doped $\mathrm{TiO}_{2}$ coatings. It is closely related to the mechanisms that occurred on the cathode branch. $\mathrm{The}_{\mathrm{TiO}}$ oxide layer acts on the cathode branch, increasing the slope of the cathode reaction. This suggests the presence of cathodic inhibition and a significant increase in the kinetics of the anode reaction. Therefore, the effect of the passivation process might be imperceptible on the obtained polarization curves, and the passive oxide film formed on coated samples might be thermodynamically unstable. 


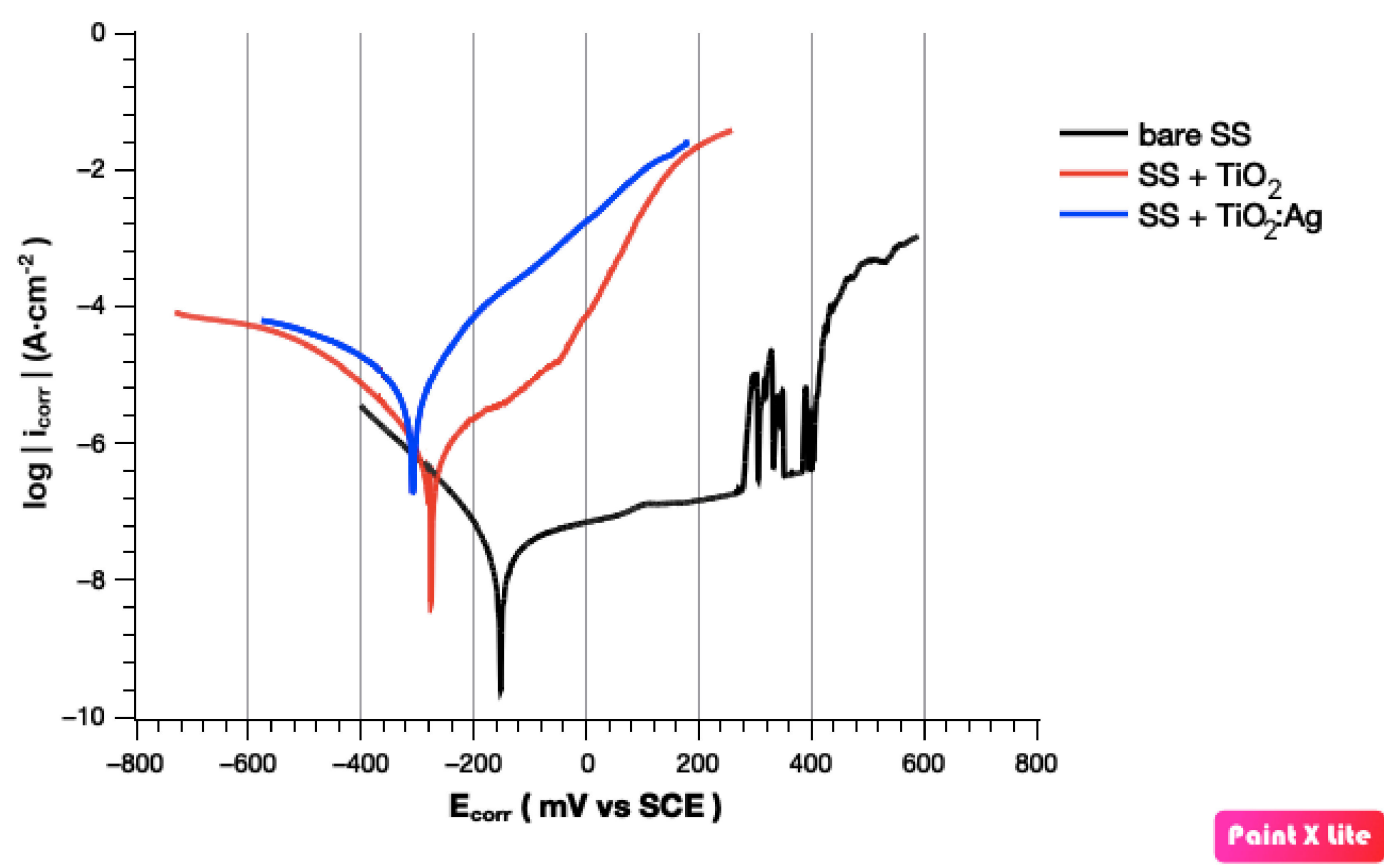

Figure 6. Potentiodynamic polarization curves of bare, $\mathrm{TiO}_{2}$ coated and Ag-doped $\mathrm{TiO}_{2}$ coated selected samples.

\section{Discussion}

The oral cavity is inhabited by more than 700 species of Gram-positive and Gramnegative bacteria, occurring in planktonic form or in the form of an organized structure. Individual components of dental braces, due to their irregular surface, provide an ideal place for plaque formation [28]. Dental plaque is a typical biofilm associated with the surface of teeth, which may cause damage to the enamel structure and periodontal damage, and even contribute to the development of ischemic heart disease. Dental plaque is formed by both supragingival and subgingival bacteria, usually Streptococcus, Actinomyces, Lactobacillus, Porphyromonas, Tannerella, Fusobacterium, Prevotella, Bacteroides, Spirochaetes [3,4]. In addition to the mechanical removal of dental plaque and the use of preparations containing agents with antimicrobial properties, the use of nanoparticles that exhibit bacteriostatic/bactericidal properties is a promising strategy for reducing bacterial adhesion to biomaterials [29-31]. Mhaske et al. investigated the impact of coating of stainless steel and nickel-titanium archwires with a layer containing silver on the survival of Lactobacillus acidophilus. Compared to the uncoated archwires, here there was a statistically significant decrease in the survival of bacteria found on coated archwires [13]. Silver is well known for its antimicrobial activity against Gram-positive and negative bacteria and it is widely used for medical devices. Using silver coating on the orthodontic wires prevented the adhesion of L. acidophilus, hence proving its anti-adherent properties. On the other hand, Ryu et al. observed that silver-containing and titanium-containing coating exhibited antibacterial activity against Streptococcus mutans and Aggregatibacter actinomycetemcomitans [32] Jasso-Ruiz et al. also verified the impact of silver nanoparticles on Streptococcus mutans (and Streptococcus sobrinus) and obtained similar results-reduction in bacterial load found on coated brackets [33]. The cited studies discuss an effective methodology for coating archwires with sol-gel coatings containing silver ions. Based on them, it can be concluded that such a coating may have a great potential to prevent the formation of bacterial biofilm and prevent common complications of orthodontic treatment.

The ability of bacterial colonies to adhere to specific surfaces is one of the conditions for their growth. Hence, the arch surface topography [31,34] is of key importance for the growth of bacterial colonies on it. Very rough surfaces will be more susceptible to bacterial growth, which means that the time necessary for the growth of a bacterial colony will be shorter on this surface than on one that is only slightly rough. An even distribution 
of coating on orthodontic materials with the use of antimicrobial sol-gel coatings affects their antimicrobial efficacy [35]. Moreover, the surface structure of orthodontic materials affects not only the degree of bacterial aggregation but also biocompatibility, color stability, aesthetics, and hygiene. Most studies indicate that reducing the degree of surface roughness should have a positive impact on friction as well; however, studies do not conclusively support this hypothesis [36]. It can be concluded that the smoother and more uniform the archwire surface, the better the clinical properties of the archwire.

In this study, different combinations of sol-gel coatings were analyzed; variable parameters included time and rate of emergence of the material from sol-gel, as well as the annealing time and temperature of the sample. The number of the applied layers was an additional variable that was analyzed. The SEM test confirmed that the presented method made it possible to obtain a tight and uniform layer of $\mathrm{TiO}_{2}$ and $\mathrm{TiO}_{2}: \mathrm{Ag}$, which symmetrically covered the entire surface of the tested samples. The EDS analysis also revealed the presence of $\mathrm{Ag}$ aggregates in the structure of the covering layer. The XRD analysis also showed the presence of Ag atoms in the tested sample. Therefore, it can be assumed that the presented method made it possible to effectively obtain a tight and uniform coating with potential antimicrobial activity.

The oral cavity offers ideal conditions for the phenomena of corrosion in the structure of archwires. These phenomena may secondarily have detrimental effects on both the health of the patient and the mechanical properties of archwires themselves [36,37]. The enhancement of nickel ion release under the influence of electrochemical phenomena is an additional aspect. Furthermore, corrosion and wear processes depend on biomaterial surface biofilm formation which is a natural lubrication layer decreasing further material wear processes. Due to that, applied materials for orthodontic treatments, working in a very aggressive oral environment, should have tribological, antibacterial properties and high corrosion resistance. Consequently, many researchers conducted studies on the formation of corrosion phenomena for different types of archwires, and some of these studies involved archwires with applied functional coatings [37-39]. Neuman et al. [40] demonstrated increased corrosion resistance of orthodontic wires covered with a Teflon coating. In turn, Kim and Johnson [41] demonstrated that surface modification with nitrogen ions did not increase the corrosion resistance of steel wires. It is obvious that stainless steel archwire already shows very good corrosion resistance due to the natural oxide film that covers its surfaces [42]. It is also clearly seen in Figure 6, where potentiodynamic curves were presented. The wide area of passivation and high values of polarization resistance only confirmed it.

It is also known that $\mathrm{TiO}_{2}$ coatings have good physicochemical properties and-with regard to corrosion—should shift the corrosion potential towards more positive values [43]. In this paper, we observed that cathodic inhibition might cause the formation of passive oxygen film under the $\mathrm{TiO}_{2}$ and $\mathrm{TiO}_{2}: \mathrm{Ag}$ coatings. It is possible that with an increase in the immersion time, from $1 \mathrm{~h}$ to even $24 \mathrm{~h}$ or $36 \mathrm{~h}$, the values of $\mathrm{E}_{\text {corr }}$ could be shifted in a positive direction and the polarization resistance would increase [26]. This would suggest that the material became nobler as a result of the passive layer formed on its surface. The presence of brookite in the XRD analysis just confirmed that this oxygen film is thermodynamically unstable. What is more, there is a high probability of the occurrence of oxygen vacancies. Therefore, it would be reasonable to carry out a long-term incubation to produce thermodynamical, stable $\mathrm{TiO}_{2}$. It could make it possible for polarization resistance to be increased, and the $\mathrm{E}_{\text {corr }}$ value to be shifted towards a more positive direction. The low $E_{\text {corr }}$ and $R_{p}$ rates may also indicate heterogeneity of the coatings or the presence of precipitations. Thermodynamic stability may not be achieved due to these defects. Further research is needed to investigate the passivation ability for the barrier properties of sol-gel layers. 


\section{Conclusions}

The authors of the present study verified the selected properties of stainless steel orthodontic archwires coated with $\mathrm{TiO}_{2}: \mathrm{Ag}$. Based on the SEM and XRD analysis, opencircuit potential measurement, and potentiodynamic polarization, it was observed that the SEM analysis did not reveal cracking or delamination of the obtained $\mathrm{TiO}_{2}: \mathrm{Ag}$ coating, and the XRD analysis revealed the presence of Ag nanoparticles, which indicates that the layer applied to stainless steel orthodontic archwires have antibacterial potential. The authors of the study investigated the electrochemical behavior of stainless steel orthodontic archwires with $\mathrm{TiO}_{2}$ and $\mathrm{TiO}_{2}: \mathrm{Ag}$, compared to bare orthodontic $316 \mathrm{~L}$ archwires in simulated body fluids. It was observed that $\mathrm{TiO}_{2}: \mathrm{Ag}$ coatings can change the microstructure and electrochemical behavior of stainless steel. During electrochemical tests, the authors observed a thermodynamically unstable layer of $\mathrm{TiO}_{2}$, and cathodic inhibition caused by a short time of incubation in Ringer's solution. It would be reasonable to conduct incubation over a longer period of time (24-36 h) to check the passivation ability for the barrier properties of sol-gel layers. In summary, further studies, especially mechanical and tribological, on the created layers should be conducted. Antimicrobial potential of the $\mathrm{TiO}_{2}: \mathrm{Ag}$ layer should be checked using strains of bacteria inhabiting the oral cavity. Studies on the cytotoxic effect of the developed layer on human cells are also necessary. Biocompatibility and antibacterial studies are currently underway at the Medical University of Wroclaw. If its significant antimicrobial or bacteriostatic effect on microorganisms inhabiting the oral cavity is confirmed and its detrimental impact on human cells is ruled out, it will be possible to initiate the stage of clinical trials and assess the effectiveness of the layer in vivo.

Author Contributions: Conceptualization, M.S.; methodology, J.B., A.Z., Z.K.-G.; validation, Z.K.-G., M.G.-M., J.B., A.Z.; formal analysis, J.B., A.Z., B.B., W.S.; investigation, J.B., A.Z., B.B., W.S.; resources, Z.K.-G., M.G.-M., writing—original draft preparation, Z.K.-G., M.G.-M., J.B., A.Z.; writing—review and editing, M.S., B.K., J.D., B.B.; visualization, Z.K.-G., J.B., A.Z.; supervision M.S., B.K., J.D., B.B.; project administration, M.S., J.D.; funding acquisition J.D., B.K. All authors have read and agreed to the published version of the manuscript.

Funding: The cost of the publication was funded by Academic Dental Polyclinic of Dental Center of Technology Transfer Ltd., Krakowska Str. 26, 50-425 Wroclaw, Poland.

Institutional Review Board Statement: Not applicable.

Informed Consent Statement: Not applicable.

Conflicts of Interest: The authors declare no conflict of interest. The funders had no role in the design of the study; in the collection, analyses, or interpretation of data; in the writing of the manuscript, or in the decision to publish the results.

\section{References}

1. Mazur, T.; Postek-Stefańska, L.; Wysoczańska-Jankowicz, I.; Pietraszewska, D.; Borkowski, L.; Jodlawska, A.; Bak-Kus, M. Powikłania Leczenia Ortodontycznego Aparatami Stałymi i Ruchomymi u Pacjentów w Wieku Rozwojowym. Implant. Stomatol. Klin. 2008, 9, 34-38.

2. Kozak, U.; Dunin-Wilczyńska, I. Biofilm w Ortodoncji-Cz. 1. Orthod. Forum 2014, 10, 41-46.

3. Pasich, E.; Walczewska, M.; Pasich, A.; Marcinkiewicz, J. Mechanism and Risk Factors of Oral Biofilm Formation. Posteppy Hig. Med. Doświadczalnej 2013, 67, 736-741. [CrossRef] [PubMed]

4. Brown, J.L.; Johnston, W.; Delaney, C.; Short, B.; Butcher, M.C.; Young, T.; Butcher, J.; Riggio, M.; Culshaw, S.; Ramage, G. Polymicrobial Oral Biofilm Models: Simplifying the Complex. J. Med. Microbiol. 2019, 68, 1573-1584. [CrossRef] [PubMed]

5. Strużycka, I. Biofilm—Współczesne Spojrzenie Na Etiologię Próchnicy. Dent. Forum 2010, 38, 73-79.

6. Limoli, D.H.; Jones, C.J.; Wozniak, D.J. Bacterial Extracellular Polysaccharides in Biofilm Formation and Function. Microbiol. Spectr. 2015, 3, 3. [CrossRef]

7. Vu, B.; Chen, M.; Crawford, R.; Ivanova, E. Bacterial Extracellular Polysaccharides Involved in Biofilm Formation. Molecules 2009, 14, 2535-2554. [CrossRef]

8. Kim, I.-H.; Park, H.-S.; Kim, Y.K.; Kim, K.-H.; Kwon, T.-Y. Comparative Short-Term In Vitro Analysis of Mutans Streptococci Adhesion on Esthetic, Nickel-Titanium, and Stainless-Steel Arch Wires. Angle Orthod. 2014, 84, 680-686. [CrossRef] [PubMed] 
9. Bradley, T.G.; Berzins, D.W.; Valeri, N.; Pruszynski, J.; Eliades, T.; Katsaros, C. An Investigation into the Mechanical and Aesthetic Properties of New Generation Coated Nickel-Titanium Wires in the as-Received State and after Clinical Use. Eur. J. Orthod. 2014, 36, 290-296. [CrossRef]

10. Da Silva, D.L.; Mattos, C.T.; Anna, E.F.S.; Ruellas, A.C.d.O.; Elias, C.N. Cross-Section Dimensions and Mechanical Properties of Esthetic Orthodontic Coated Archwires. Am. J. Orthod. Dentofac. Orthop. 2013, 143, S85-S91. [CrossRef]

11. Katić, V.; Ćurković, H.O.; Semenski, D.; Baršić, G.; Marušić, K.; Špalj, S. Influence of Surface Layer on Mechanical and Corrosion Properties of Nickel-Titanium Orthodontic Wires. Angle Orthod. 2014, 84, 1041-1048. [CrossRef]

12. Elayyan, F.; Silikas, N.; Bearn, D. Ex Vivo Surface and Mechanical Properties of Coated Orthodontic Archwires. Eur. J. Orthod. 2008, 30, 661-667. [CrossRef]

13. Mhaske, A.R.; Shetty, P.C.; Bhat, N.S.; Ramachandra, C.S.; Laxmikanth, S.M.; Nagarahalli, K.; Tekale, P.D. Antiadherent and Antibacterial Properties of Stainless Steel and NiTi Orthodontic Wires Coated with Silver against Lactobacillus Acidophilus-An in Vitro Study. Prog. Orthod. 2015, 16, 40. [CrossRef]

14. Zakaria, M.B.; Elmorsi, M.A.; Ebeid, E.-Z.M. Nanostructured $\mathrm{TiO}_{2}$ Coated Stainless Steel for Corrosion Protection. J. Nanosci. Nanotechnol. 2016, 16, 9215-9222. [CrossRef]

15. Mollabashi, V.; Farmany, A.; Alikhani, M.Y.; Sattari, M.; Soltanian, A.R.; Kahvand, P.; Banisafar, Z. Effects of TiO ${ }_{2}$-Coated Stainless Steel Orthodontic Wires on-Streptococcus Mutans-Bacteria: A Clinical Study. Int. J. Nanomed. 2020, 15, 8759-8766. [CrossRef]

16. Gonçalves, I.S.; Viale, A.B.; Sormani, N.N.; Pizzol, K.E.D.C.; de Araujo-Nobre, A.R.; de Oliveira, P.C.S.; Barud, H.G.d.O.; Antonio, S.G.; Barud, H.d.S. Antimicrobial Orthodontic Wires Coated with Silver Nanoparticles. Braz. Arch. Biol. Technol. $2020,63$. [CrossRef]

17. Arango, S.; Peláez-Vargas, A.; García, C. Coating and Surface Treatments on Orthodontic Metallic Materials. Coatings 2012, 3 , 1-15. [CrossRef]

18. Jilani, A.; Abdel-Wahab, M.S.; Hammad, A.H. Advance Deposition Techniques for Thin Film and Coating. 2017. Available online: https: / / www.intechopen.com/chapters/52684 (accessed on 10 July 2021). [CrossRef]

19. Sajjadi, S.P. Sol-Gel Process and Its Application in Nanotechnology. J. Polym. Eng. Technol. 2005, 13, 38-41.

20. Rao, A. Modeling Bending Response of Shape Memory Alloy Wires/Beams under Superelastic Conditions-A Two Species Thermodynamic Preisach Approach. Int. J. Struct. Chang. Solids 1992, 5, 1-26.

21. Özyildiz, F.; Uzel, A.; Hazar, A.S.; Güden, M.; Ölmez, S.; Aras, I.; Karaboz, İ. Photocatalytic Antimicrobial Effect of TiO 2 Anatase Thin-Film-Coated Orthodontic Arch Wires on 3 Oral Pathogens. Turk. J. Biol. 2014, 38, 289-295. [CrossRef]

22. Tomás, S.A.; Luna-Resendis, A.; Cortés-Cuautli, L.C.; Jacinto, D. Optical and Morphological Characterization of Photocatalytic $\mathrm{TiO}_{2}$ Thin Films Doped with Silver. Thin Solid Films 2009, 518, 1337-1340. [CrossRef]

23. Stern, M.; Geary, A.L. Electrochemical Polarization, 1. A Theoretical Analysis of the Shape of Polarization Curves. J. Electrochem. Soc. 1957, 104, 56-63. [CrossRef]

24. Pérez-Quiroz, J.T.; Terán, J.; Herrera, M.J.; Martínez, M.; Genescá, J. Assessment of Stainless Steel Reinforcement for Concrete Structures Rehabilitation. J. Constr. Steel Res. 2008, 64, 1317-1324. [CrossRef]

25. Karimi, M.H.S.; Yeganeh, M.; Zaree, S.R.A.; Eskandari, M. Corrosion Behavior of 316L Stainless Steel Manufactured by Laser Powder Bed Fusion (L-PBF) in an Alkaline Solution. Opt. Laser Technol. 2021, 138, 106918. [CrossRef]

26. Hitchman, M.L.; Meldrum, G.; Tsai, W.T.; Walsh, F.C. An Investigation of the Relative Roles of Kinetics and Transport in Cathodic Inhibition. Corros. Sci. 1994, 36, 1237-1246. [CrossRef]

27. Yetim, T. An Investigation of the Corrosion Properties of Ag-Doped $\mathrm{TiO}_{2}$-Coated Commercially Pure Titanium in Different Biological Environments. Surf. Coat. Technol. 2017, 309, 790-794. [CrossRef]

28. Müller, L.K.; Jungbauer, G.; Jungbauer, R.; Wolf, M.; Deschner, J. Biofilm and Orthodontic Therapy. Monogr. Oral Sci. 2021, 29, 201-213.

29. Benoit, D.S.W.; Sims, K.R.; Fraser, D. Nanoparticles for Oral Biofilm Treatments. ACS Nano 2019, 13, 4869-4875. [CrossRef]

30. Bacela, J.; Łabowska, M.B.; Detyna, J.; Zięty, A.; Michalak, I. Functional Coatings for Orthodontic Archwires-A Review. Materials 2020, 13, 3257. [CrossRef] [PubMed]

31. Venkatesan, K.; Kailasam, V.; Padmanabhan, S. Evaluation of Titanium Dioxide Coating on Surface Roughness of Nickel-Titanium Archwires and Its Influence on Streptococcus Mutans Adhesion and Enamel Mineralization: A Prospective Clinical Study. Am. J. Orthod. Dentofac. Orthop. 2020, 158, 199-208. [CrossRef]

32. Ryu, H.-S.; Bae, I.-H.; Lee, K.-G.; Hwang, H.-S.; Lee, K.-H.; Koh, J.-T.; Cho, J.-H. Antibacterial Effect of Silver-Platinum Coating for Orthodontic Appliances. Angle Orthod. 2012, 82, 151-157. [CrossRef] [PubMed]

33. Jasso-Ruiz, I.; Velazquez-Enriquez, U.; Scougall-Vilchis, R.J.; Morales-Luckie, R.A.; Sawada, T.; Yamaguchi, R. Silver Nanoparticles in Orthodontics, a New Alternative in Bacterial Inhibition: In Vitro Study. Prog. Orthod. 2020, 21, 24. [CrossRef] [PubMed]

34. Abraham, K.S.; Jagdish, N.; Kailasam, V.; Padmanabhan, S. Streptococcus Mutans Adhesion on Nickel Titanium (NiTi) and Copper-NiTi Archwires: A Comparative Prospective Clinical Study. Angle Orthod. 2017, 87, 448-454. [CrossRef] [PubMed]

35. Oliveira, A.S.; Kaizer, M.R.; Azevedo, M.S.; Ogliari, F.A.; Cenci, M.S.; Moraes, R.R. (Super)Hydrophobic Coating of Orthodontic Dental Devices and Reduction of Early Oral Biofilm Retention. Biomed. Mater. 2015, 10, 065004. [CrossRef]

36. Ghasemi, T.; Arash, V.; Rabiee, S.M.; Rajabnia, R.; Pourzare, A.; Rakhshan, V. Antimicrobial Effect, Frictional Resistance, and Surface Roughness of Stainless Steel Orthodontic Brackets Coated with Nanofilms of Silver and Titanium Oxide: A Preliminary Study. Microsc. Res. Tech. 2017, 80, 599-607. [CrossRef] 
37. Ogawa, C.M.; Faltin, K.; Maeda, F.A.; Ortolani, C.L.F.; Guaré, R.O.; Cardoso, C.A.B.; Costa, A.L.F. In Vivo Assessment of the Corrosion of Nickel-Titanium Orthodontic Archwires by Using Scanning Electron Microscopy and Atomic Force Microscopy. Microsc. Res. Tech. 2020, 83, 928-936. [CrossRef]

38. Abalos, C.; Paúl, A.; Mendoza, A.; Solano, E.; Gil, F.J. Influence of Topographical Features on the Fluoride Corrosion of Ni-Ti Orthodontic Archwires. J. Mater. Sci. Mater. Med. 2011, 22, 2813-2821. [CrossRef]

39. Huang, H.-H. Surface Characterizations and Corrosion Resistance of Nickel-Titanium Orthodontic Archwires in Artificial Saliva of Various Degrees of Acidity. J. Biomed. Mater. Res. Part A 2005, 74A, 629-639. [CrossRef]

40. Neumann, P.; Bourauel, C.; Jäger, A. Corrosion and Permanent Fracture Resistance of Coated and Conventional Orthodontic Wires. J. Mater. Sci. Mater. Med. 2002, 13, 141-147. [CrossRef]

41. Kim, H.; Johnson, J.W. Corrosion of Stainless Steel, Nickel-Titanium, Coated Nickel-Titanium, and Titanium Orthodontic Wires. Angle Orthod. 1999, 69, 39-44.

42. Ćurković, L.; Ćurković, H.O.; Salopek, S.; Renjo, M.M.; Šegota, S. Enhancement of Corrosion Protection of AISI 304 Stainless Steel by Nanostructured Sol-Gel $\mathrm{TiO}_{2}$ Films. Corros. Sci. 2013, 77, 176-184. [CrossRef]

43. Yerokhin, A.; Khan, R.H.U. Anodising of light alloys. In Surface Engineering of Light Alloys, Anodising of Light Alloys, Aluminium, Magnesium and Titanium Alloys; Woodhead Publishing: Sawston, UK, 2010; pp. 83-109. 